\section{KAJIAN MUSIKAL PERTUNJUKAN SOLIS BIOLA}

\section{Fu'adi}

\section{Fakultas Bahasa dan Seni Universitas Negeri Yogyakarta}

\section{Abstrak}

Pertunjukan solis biola yang menjadi bahan kajian ini bukanlah pertunjukan langsung dari sebuah gedung konser namun dari rekaman pertunjukan audio visual (DVD). Dengan mengkaji secara musikal diharapkan dapat menemukan beberapa hal yang berguna untuk menambah wawasan dalam upaya meningkatkan ketrampilan bermain musik. Menjadi musisi yang handal tentu saja membutuhkan ketekunan, kedisiplinan, kerja keras dan melalui proses tati saja mo panjang. Penguasaan atas suatu instrumen musik, gitar ata proses latihan yang panjang. Penguasaan atas sutu instu misalnya, selain belajar dengan guru musik perlu juga melengkapi referensi dengan buk-buku mar denguti workshop maupun seminar tentang musik, mendengar dan melihat kaset-kaset rekaman musik.

Beberapa rekaman solis biola kelas dunia seperti Isaac Stern, Itzak Perlman, Henryk Szeryng dan lainnya dapat memberikan gambaran bagaimana seharusnya musik yang bagus itu dipertunjukkan. Berbagai teknik permainan biola, seperti bowing dan fingering yang dipergunakan para solis dalam memainkan komposisi-komposisi terkenal seperti konserto karya Mozart, Beethoven, Mendelssohn akan dibahas dalam tulisan ini walaupun tidak secara utuh dan kiranya dapat menjadi salah satu penunjang dalam proses pembelajaran biola.

Kata kunci : pertunjukan musik, solis biola, kajian musikal

\section{PENDAHULUAN}

Kebutuhan akan sarana pendukung belajar seperti buku-buku ataupun kaset rekaman dalam bidang kesenian tentulah tak bisa diabaikan. Dalam seni musik misalnya, untuk membedakan jenis-jenis musik tak hanya dapat dijelaskan dengan uraian yang panjang lebar namun haruslah disertai dengan contoh bunyi musik itu sendiri sebagai wujud dari objek yang dibahas. Masih terbatasnya kegiatan workshop musik ataupun acara resital musik klasik di tanah air khususnya di kota Yogjakarta tentu mempengaruhi gairah dan semangat dalam mengembangkan aktivitas musik klasik yang sering dikenal dengan musik serius tersebut. Penyelenggaraan kegiatan pentas musik klasik memang seharusnya dipelopori oleh sekolah, kampus atau kursus-kursus yang memposisikan diri di jalur seni. Beberapa bentuk pentas musik seperti Home Concert, Night Concert, Welcome maupun Farewell Concert sangat bagus sebagai ajang berkreasi dan berapresiasi musik. Di sisi lain biaya yang tinggi dan kurangnya kesempatan menjadi kendala tersendiri tatkala muncul keinginan untuk dapat melihat secara langsung pertunjukan musik oleh musisi dunia di gedung konser yang mempunyai kualitas akustik berstandar internasional. Memang ada sebagian musisi yang mendapat kesempatan belajar atau sekedar mengikuti workshop di luar negeri namun jumlahnya masih dapat dihitung dengan jari. Dengan adanya perkembangan teknologi, sesuatu hal baru yang merupakan salah satu unsur penting dalam musik, disebut dengan transmisi bunyi; yang mencapai wilayah luas melalui radio dan televisi, telah menjadikan musik dapat dinikmati oleh sejumlah besar para pendengar pada seketika musik itu dipergelarkan. Fonograf (meliputi piringan hitam, pita dan kabel perekam) serta jalur bunyi film adalah unsur-unsur mekanik yang menyebabkan musik secara tidak langsung dapat dinikmati publik pendengar yang luas, dikatakan tidak langsung karena adanya perbedaan waktu antara pertunjukan yang sebenarnya dengan pendengar yang menerimanya (Hugh M.Miller dalam terjemahan Bramantyo : 4 ). Merupakan angin segar bagi para pecinta musik bahwa dengan kemajuan teknologi, musik dari berbagai penjuru dunia dapat dengan mudah diperdengarkan, misalnya dalam bentuk kaset musik klasik, jazz, pop dan latin.

Penulis mencoba melacak kaset DVD musik klasik yang berisi beberapa konserto biola yang dimainkan oleh para solis biola ternama. Ada beberapa hal yang menarik dari kaset DVD tersebut, selain memiliki kualitas gambar dan suara yang lebih baik dibandingkan kaset generasi sebelumnya, dapat juga dipergunakan sebagai salah satu bahan referensi dalam upaya mempelajari musik klasik barat, khususnya dalam seni permainan biola. Hal-hal yang menarik tersebut akan kita singgung dalam pembahasan berikutnya.

Dengan hadirnya kaset DVD tentang pertunjukan solis biola, penulis akan mencoba mengkaji secara musikal yaitu dengan menganalisa teknik yang dipergunakan oleh para solis biola dalam memainkan konserto-konserto biola terkenal dari para komposer besar seperti Mozart, Beethoven, Mendelssohn, Tschaikowsky dan Max Bruch. Selain pembahasan teknik tangan kanan dan kiri terutama juga pembahasan tentang penggunaan bowing (teknik gesekan) dan fingering (teknik penjarian).

\section{MENGENAL BIOLA DAN SOLIS BIOLA}

\section{Mengenal Alat Musik Biola}

Biola merupakan salah satu alat musik gesek yang mempunyai sejarah yang panjang. Bentuk biola yang seperti kita kenal sekarang ternyata mengalami perkembangan yang luarbiasa, dari bentuk yang masih sangat sederhana sampai ke bentuk sempurna yang dibuat oleh Antonio Stradivari. Instrumen gesek di abad pertengahan dan Renaissance merupakan pelopor dari biola modern. Dua bentuk utama dari instrumen musik gesek abad pertengahan adalah Fiddle dan Rebec yang digunakan oleh Troubador untuk mengiringi nyanyian dan tarian. Lira da Braccio dikembangkan dari instrumen Fiddle di akhir abad 14 dan mempunyai 
keistimewaan dan karakter yang mirip dengan biola modern (Midgley, 1976).

Menurut Curt sach, biola termasuk dalam kelompok alat musik

Chordhophone, yaitu alat musik yang sumber bunyinya berasal dari senar yang bergetar. Ada 5 bentuk dasar dari alat musik Chordophone yaitu Bows (berbentuk busur), Lyra, Harp, Lute dan Zithers. Di sini, alat musik Bows adalah yang tertua dan paling sederhana bentuknya dimana sampai sekarang masih dipergunakan di Afrika dan Amerika. Harp dan Lira muncul sekitar 5000 tahun yang lalu di Ancient Egypt dan Sumeria. Harpa berkembang di banyak belahan dunia. Lute juga mempunyai sejarah yang panjang dan menjadi alat musik yang paling terkenal di antara alat musik yang lain. Bow (busur penggesek) pertama kali ditambahkan dalam permainan Lute di abad $10 \mathrm{M}$, lalu berkembang alat-alat musik yang kemudian menjadi anggota keluarga biola. Zithers muncul dengan variasi dan bentuk yang luas, berkembang dari zither pipa yang sederhana sampai keyboard canggih di Eropa (Midgley, 1976).

Lute adalah salah satu alat musik yang populer di Eropa pada jaman Renaissance. Walaupun bentuknya sama dengan alat musik yang dikenal di awal 2000 tahun sebelum Masehi di Mesopotamia dan 1500 tahun sebelum Masehi di Egypt, Lute baru muncul di Eropa di abad 10 M. Pada abad 15 Lute menjadi alat yang sering digunakan sebagai pasangan dan instrumen pengiring dan tetap populer di Eropa barat selama 200 tahun. Alat musik Lute terdiri dari badan resonansi di leher, dan mempunyai senar yang dihubungkan dekat bagian bawah badan ke sepanjang leher Lute (Midgley, 1976).

Alat musik lain yang termasuk dalam masa awal perkembangan alat musik gesek adalah Rebec, yang kemungkinan alat musik aslinya berasal dari penduduk di negara-negara muslim (seperti Rebab atau Rabab dari Arab). Rebec mulai dikenal di Eropa pada Abad 13. Rebec mempunyai pahatan kayu di sekeliling bagian belakang dan dengan tambahan papan suara yang datar. Di masa renaissance terdapat beberapa ukuran dan tinggi rendah nada pada alat musik Rebec, seperti sopran, tenor dan bass. Tenor dan bass kemungkinan dimainkan seperti gaya memainkan Gamba, dijepit diantara kedua lutut. Versi yang lebih kecil dikenal dengan nama Ribecchino (latin) atau Rubechette (Perancis) (Kennedy, 1994).

Viol adalah pendahulu dari alat musik biola yang berkembang di abad 16 Walaupun secara fisik mirip dengan biola, Viol mempunyai ciri yang khas, yaitu pada bagian leher mempunyai frets yang merupakan karakteristik Lute pada jaman renaissance. Viol memiliki suara yang lembut dan merdu, sehingga alat musik in lebih pantas atau cocok dimainkan di dalam rumah dan sebagai musik kamar daripada di gedung konser yang besar. Perbedaan yang lain dengan biola modern yaitu pada bagian belakang Viol permukaannya datar dan memiliki 6 buah senar sementara biola modern mempunyai bagian belakang yang permukaannya cembung dan memiliki senar yang berjumlah 4 buah.

Perkembangan awal biola, yaitu pada akhir tahun 1520, biola masih menggunakan 3 buah senar, hal ini dapat dilihat dari periode ikonografi pada waktu itu. Salah satu lukisan biola waktu itu yang berangka tahun 1529 yang dibuat oleh Gaudinzio Ferrari ditemukan. Baru pada tahun 1550, senar keempat, senar yang paling tinggi "e" ditambahkan (Randel, 1986). Andrea Amati,(1511-1580) sebagai pelopor pembuat biola di Cremona, Italia, mengembangkan proporsi bentuk dasar biola, Viola dan Cello. Kedua anak lelakinya yaitu Antonio (1540-?) dan Girolamo (Hieronymous)(1561-1630) melanjutkan pekerjaan ayahnya membuat biola, memperbaiki bentuk badan biola, membuat lubang suara (f-hole), ukiran-ukiran kayu, dan scroll. Antonio dan Girolamo selalu bekerjasama dan memberikan label secara bersama-sama.

Setelah Girolamo Amati meninggal di tahun 1630, anak lelakinya yang bernama Nicolo Amati (1596-1684) meneruskan karir ayahnya dan menjadi salah satu pembuat biola terpenting di Italia. Pengembangan pembuatan biolanya dengan cara menghubungkan beberapa bagian dan ketelitiannya untuk membuat kualitas suara menjadi lebih baik dan pengaruhnya sebagai guru mencetak generasi baru para pembuat biola terkenal, seperti Andrea Guarneri, Francesco Rugeri, dan Antonio Stradivari. Jacob Stainer juga mendapat pelajaran dari Nicolo Amati (Randel, 1986).

Pembuat biola yang bernama Antonio Stradivari (1644-1737) adalah tokoh yang menyempurnakan bentuk, simetri, dan keindahan biola. Stradivari disebut oleh semua orang sebagai pembuat biola terbesar sepanjang sejarah. Setelah tahun 1690, Stradivari meninggalkan model popular Amati dan membuat ukuran yang baku untuk biola (14 5/16 inchi). Dalam dekade yang sama, teknologi bertambah maju dimana senar dari usus binatang ditutup dengan lilitan metal, lilitan metal membuat respon dan konsentrasi suara yang cepat dan mampu menambah ketegangan. Dengan teknologi senar yang baru, Stradivari meninggalkan ukuran biola yang panjang setelah tahun 1700 lalu membuat model baru yang panjangnya tepat 14 inchi $(35.5 \mathrm{~cm})$ dengan kuat dan lurus. Ia juga membuat ukuran ini untuk cello kecil yang berukuran 29 7/8 inchi. Kedua model ini merupakan bentuk baru yang standar pada waktu itu. Seperti diketahui periode emas Stradivari berlangsung antara tahun 1700-1724.

Di Paris pada Abad 18 ada pengaruh untuk berusaha mengembangkan suara biola. Claude Pierray, Jacgues Boguay dan J.B. Solomon melanjutkan ujicoba dengan memanfaatkan ketegangan senar biola, tempat leher biola, dan dengan mengembangkan leher biola gaya perancis tahun 1740 menjadi lebih panjang $(13.4 \mathrm{~cm})$ dibanding biola buatan sekarang, dengan menambah kepanjangan senar dan badan yang tipis dapat menghasilkan suara yang sangat jelas dan cemerlang. 
Walaupun terjadi perubahan dan inovasi dalam pembuatan biola, biola buatan Nicolo Amati dan Jacob Stainer tetap eksis sampai akhir abad 18. Abad 19 tetap terjadi pengembangan pembuatan dasar-dasar biola seperti bentuk yang dipakai saat ini. Penggesek (bow) masa kini ditemukan oleh Francois Tourte (1747-1835) dengan ukuran berat, panjang dan keseimbangan yang dapat menambah kekuatan di ketegangan yang tinggi pada biola. Biola dari abad 17 dan 18 sudah mengalami medernisasi dengan penyempurnaan leher biola dan bass-bar oleh ahli pembuat biola ternama J.B. Vuillaume (1798-1875). Reputasi Stradivari didukung oleh pemain biola yang bernama Viotti dan permainan Paganini dengan biola Guarnerius menambah kepercayaan publik akan kualitas biola hasil buatan Guarneri. Gabungan leher biola dan papan jari yang tebal menyulitkan para pemain biola di abad 17. Louis Spohr lalu menemukan tempat dagu (chinrest) pada tahun 1820, sehingga dagu dapat menahan biola dan perpindahan posisi dengan tangan kiri menjadi lebih mudah. Hal ini membuka jalan kepada para musisi untuk mengembangkan teknik permainan biola modern.

\section{Mengenal Para Solis Biola}

Dengan terciptanya alat musik biola maka lahir pula para pemain biola yang dengan segala kelebihannya telah berusaha memajukan perkembangan sen musik kepada generasi-generasi berikutnya. Mereka menjadi musisi profesional dan sering bermain Solo (memainkan lagu secara tunggal baik dengan iringan atau tidak) yang pelakunya disebut dengan istilah Solis (Soloist). Secara singkat akan ditelusuri perjalanan hidup dan karakter permainan dari beberapa solis biola sehingga diharapkan dapat diperoleh sesuatu hal yang positif. Para solis biola itu diantaranya adalah sebagai berikut.

\section{Isaac Stern}

Dekade tahun 1930-an merupakan era emas dengan hadirnya beberapa pemain biola terbaik dalam sejarah. Salah satunya dalah Isaac Stern, lahir pada tanggal 21 Juli 1920 di Kriminiechz, Di Soviet ukraina, sebuah kota sekitar 350 mile baratdaya Odessa. Orangtua Stern pindah ke San Francisco sebelum Stern berusia setahun. Belajar piano di usia 6 tahun dengan Gdal Salesky lalu pindah ke biola di usia 8 tahun belajar dengan Robert Pollak. Di usia 12 tahun Stern belajar dengan Naoum Blinder, Seorang Concertmaster dari San Francisco Symphony. Stern juga murid dari Alexander Fidelman dan Adolf Brodsky dari Rusia. Bersama Blinder Stern memainkan Double Concerto karya J.S. Bach di usia 15 tahun diiringi oleh San Francisco Symphony. Beberapa tahun sebelumnya Stern menjadi solis biola dengan orkes yang sama di bawah konduktor Willy Vanderburg.

Tahun berikutmya Stern menjadi figur pemimpin untuk para pemain biola, musisi yang hebat, pendukung dan penasehat para musisi muda seperti Itzak
Perlman, Pinchas Zukerman, Slomo Mintz dan lainnya. Sebagai salah satu orang yang berpengaruh di kancah musik internasional, ia sangat berapi-api, pembicara yang sangat meyakinkan serta pendukung kamanusiaan dan kebudayaan. Terkenal sebagai penyelamat gedung konser Carnegie Hall di tahun 1960 dan usahanya mendirikan National Edowment for the Arts di tahun 1964. Stern menolak dengan tegas bermain musik di Jerman sebagai protes melawan Holocaust.

Permainan biola Isaac Stern saat dalam kondisi terbaiknya, mengkombinasikan tradisi dari teknik Pre-Soviet Russian School, yaitu dengan menitikberatkan suara biola yang bagus dan interpretasi individual yang menonjol. Karakter suaranya sepadat dan setegap penampilannya. Kelebihan Stern dalam gesekan sostenuto (ditahan; teknik permainan dengan menunda nada-nada secara halus bersambungan menurut nilai nada masing-masing), Stern menggunakan rambut bow (penggesek) sebanyak mungkin, baik ketika bermain forte (keras) ataupun pianissimo (sangat lembut).

Pegangan bow-nya berpusat di lingkaran yang dibentuk oleh jari tengah dan ibu jari, namun tanpa tekanan dan perluasan jari telunjuk seperti cara muridmurid Leopold Auer dari Russia. Stern menggunakan tekanan jari yang kuat di tangan kiri untuk menghasilkan suara biola yang maksimal, terkadang sampai terdengar jarinya memukul fingerboard (papan jari) di banyak rekamannya. Rekaman Stern sangat beragam, terdapat 160 rekaman besar dan kecil, musik kamar dan termasuk rekaman ulang dengan iringan orkestra yang berbeda.

\section{Arthur Grumiaux}

Lahir pada tgl 21 Maret 1921 di Villiers-Perwin, Wallon di propinsi Brabat, Belgia dan meninggal di Brussel tgl 16 Oktober 1986. Arthur kecil diperkenalkan dengan musik oleh kakeknya, seorang pemimpin band di Flurus, kota kecil dekat Villiers-Perwin. Setelah diajari oleh kakeknya, Arthur tampil di depan publik untuk pertama kalinya di usia 5 tahun. Tahun berikutnya ia dibawa ke Charleroi untuk masuk ke konservatori namun awalnya ditolak karena usia yang terlalu muda, Arthur baru diterima setelah diaudisi.

Selama 5 tahun Arthur pergi naik kereta ke Charleroi ditemani neneknya dan lulus di usia 11 tahun dengan mendapat Premier Prix untuk biola dan piano. Atas rekomendasi dari Direktur konservatori Charleroi, Arthur dikirim kepada Alfred Dubois di Brussel. Selama periode ini Arthur hidup susah, dua kali dalam seminggu, setiap hari jam 5 pagi pergi ke Brussel untuk belajar dan kembali jam 6 sore untuk mengikuti kelas malam di Charleroi. Dubois selalu membawa Arthur ke rumah untuk memberikan pelajaran tambahan. Di usia 18 tahun Dubois berkata bahwa sudah tidak ada lagi bahan yang bisa diajarkan untuk Arthur, lalu menyarankan pergi ke Paris untuk belajar dengan Enesco. Namun hanya semusim belajar dengan Enesco, Arthur kembali ke Brussel dan menjadi asisten Dubois. 
Beberapa tahun kamudian ketika Dubois meninggal di tahun 1949, Arthur diminta untuk menggantikan gurunya sebagai profesor di konservatori Brussel.

Arthur telah melakukan lebih dari 150 rekaman baik komposisi Mayor maupun minor, ditambah lagu-lagu trio dan ansambel. Banyak komposisi dunia yang direkam lebih dari sekali. Lagu-lagu bertempo cepat mulai dari sonata Vivaldi sampai konserto Stravinsky dan Bartok.

\section{Itzhak Perlman}

Lahir di Tel Aviv, Israel pada tahun 1945 dimana orang tuanya merupakan imigran dari Eropa timur. Perlman tertarik dengan biola di usia tiga setengah tahun dan mulai belajar pada usia 5 tahun. Namun Perlman terkena polio diusia 4 tahun dengan kaki kirinya lumpuh, sehingga ia selalu bermain biola dengan posisi duduk. Awalnya Perlman mendapat pelajaran biola selama beberapa minggu dari pemain biola kafe, lalu pergi ke akademi musik di Tel Aviv dan belajar dengan Rivka Goldgart selama 8 tahun.

Di usia 13 tahun Perlman dibawa ke Amerika Serikat untuk tampil di acara Ed Sullivan Television show memainkan bagian Finale konserto Mendelssohn dan Flight of Bumble Bee dengan sangat mengesankan. Namun Perlman tetap harus meneruskan belajarnya dan memperluas lagu-lagu yang masih dianggap terbatas. Di Juilliard Perlman belajar dengan Ivan Galamian dan terkadang dengan Dorothy Delay. Kemudian di Galamian's Meadowmount School for String, Perlman bekerja dengan Josef Gingold di musik kamar. Isaac Stern juga membantu perkembangan Perlman dengan sangat baik.

Permainan biola Perlman sangat ekspresif, terutama dalam musik romantik. Dengan ukuran jari tangan yang besar, Perlman dapat dengan muda menguasai seluruh papan jari dan berubah posisi hanya dengan meregangkan jari-jarinya, seperti hal yang dilakukan oleh para pemain biola kontemporer Perlman telah melakukan rekaman dengan repertoar yang luas, rekaman permainannya hampir sebanyak pertunjukan langsungnya. Dalam jumlahnya, rekamannya melebihi rekaman Kreisler, Milstein, Francescatti dan Stern.

\section{Henryk Szeryng}

Lahir tgl 22 september 1918 di Zeazowa Wola, sebuah pegunungan di pinggir Warsawa dimana Chopin (pianis dunia) juga lahir disana. Ayahnya adalah seorang pemilik industri yang kaya raya, sedangkan ibunya adalah seorang pemain piano yang merasa bertanggung jawab untuk mengenalkan pelajaran musik kepada anaknya. Di usia 5 tahun ia mengajarkan piano dan ilmu harmoni lalu di usia 7,5 tahun Henryk mulai belajar biola dengan Maurice Frenkel, salah satu asisten dari Leopold Auer. Dengan Frenkel Szeryng diajarkan intonasi yang akurat dan teknik double-stop untuk membentuk dan mempertahankan penguasaan teknik.

Kemajuan Szeryng kecil sangat pesat, mendekati usia 10 tahun sudah mampu memainkan konserto Mendelssohn di depan solis biola Bronislaw Huberman, yang lalu menganjurkannya untuk belajar dengan Hess, Flesch atau Jacques Thibaud. Suara permainan biola Szeryng sangat merdu, memancarkan kehangatan dalam diri seseorang yang dapat menghanyutkan perasaan pendengarnya. Vibratonya secara umum tidak terlalu cepat namun ia mampu menghasilkan tingkat intensitas yang tinggi di puncak kalimat musik, terutama di nada-nada tinggi pada senar E.

\section{Zino Francescatti}

Lahir di Marseille, Prancis, 9 Agustus 1902. Di usia 5 tahun belajar biola dangan ayahnya yang seorang pemain dan guru biola. Bersama kedua orangtuanya dan murid-murid yang lain Zino bermain biola di rumah yang besar siang dan malam. Zino adalah seorang murid yang punya kemauan keras, di usia kanak-kanak ia berlatih biola 1 jam sebelum berangkat ke sekolah dan 1 jam setelah pulang sekolah. Ia rajin berlatih etude sevcik, Kreutzer dan Gavinies, latihan double-stop, trill dan harmonics.

Di usia 10 tahun Zino mampu memainkan konserto Beethoven. Zino tergolong mempunyai teknik nomor satu. Koordinasi antara tangan kanan dan kiri sangat baik. Jari-jarinya tidak melebihi ukuran normal namun sangat fleksibel di atas fingerboard. Permainan spiccato-nya (teknik menggesek dengan bow melompat dan cepat) sangat terkontrol dan staccato (gesekan pendek dengan efek suara terputus-putus) di atas senarnya sangat mantap. 110 komposisi besar dan kecil telah direkam oleh Zino. Pada pertengahan 1940-1950 banyak dari rekaman terbaiknya dibuat dalam bentuk mono dan stereo awal.

\section{Erica Morini}

Murid dari Sevcik dan Rosa Hochman, Morini mempunyai prestasi yang gemilang dengan keahlian dan ketenarannya, sangat musikal, permainannya sangat teknis, intonasinya akurat dan artikulasinya tepat. Morini adalah pemain biola perempuan pertama yang merekam komposisi besar seperti konserto dari Beethoven, Tschaikovsky, Mendelssohn, Brahm, Bruch, Mozart, Bach, Wieniawsky, musik-musik barok, sonata klasik dan romantik.

\section{Pertunjukan Solis Biola dalam Kajian Musikal}

Pertunjukan solis biola yang akan dikaji ini merupakan rekaman dari para pemain biola yang memainkan beberapa lagu / komposisi terkenal karya Mozart, Beethoven, Tchaikowsky dan lainnya. Penggunaan penggesek/bow (bowing) dan 
sistem penjarian (fingering) yang dipergunakan oleh para solis menjadi unsur utama dalam pengkajian ini. Gesekan turun menggunakan simbol )" sedangkan gesekan naik menggunakan simbol ". Dalam sistem penjarian tangan kiri dengan simbol angka 1 (telunjuk), 2 (jari tengah), 3 (jari manis) dan 4 (kelingking). Pembahasan diawali dengan lawatan Isaac Stern ke negeri Cina di tahun 1979 yang didokumentasikan dalam film "from Mao To Mozart" yang telah memenangkan oscar dalam kategori film dokumenter. Stern memberikan workshop musik kepada para musisi di Cina khususnya tentang teknik bermain biola. Pemerintah Cina membuat langkah yang tepat dengan mengundang seseorang yang profesional di bidangnya yaitu Isaac Stern, sebagai upaya dalam mempelajari kebudayaan (bidang musik) dari negara lain untuk kemajuan perkembangan musik di Cina.

Pada kesempatan itu Stern memainkan Concerto in G Mayor karya Mozart bersama The Central Philharmonic dengan konduktor Li Delum. Stern mengajarkan teknik untuk memainkan komposisi karya Mozart, penggarapan dinamik, memberikan warna-warna yang berbeda di setiap tema lagu, merubah teknik bermain biola yang selama ini selalu mengikuti gaya lama, memberikan pemahaman langsung dan rangsangan musikal kepada para pemain orkes akan hal-hal yang harus dilakukan terhadap not-not yang ada di partitur, sehingga permainan musik mereka lebih hidup bukan hanya not yang mengalir saja tanpa ekspresi. Dengan pengalaman dan pengetahuan musik barat yang terbatas, para pemain orkes saat mengikuti sesi latihan dengan Stern terkesan kaku dan raguragu, sedikit kelelahan dan tidak terbiasa bermain musik dengan bergairah dan bersemangat.

Dalam workshopnya Stern mengemukakan bahwa para musisi di Cina mempunyai kesalahan yang sama dalam menggunakan bow (penggesek). Ibarat bermain pingpong tangan yang bergerak memukul tidak boleh distop secara mendadak karena otot tangan akan terasa sakit, demikian juga dalam menggesek biola terkadang saat posisi bow di pangkal secara tidak sadar terangkat sehingga kalimat musiknya terputus. Stern mencontohkan bagaimana bermain dengan bow yang menyeluruh, tidak menghentikan gerakan dengan tiba-tiba dan bow selalu menempel dengan senar biola.

Stern menekankan bahwa untuk membuat kalimat musik lebih hidup pikiran pemain harus lebih dahulu berusaha menyanyikan melodi yang akan dimainkan, kemudian baru diekspresikan (dibunyikan) dengan instrumen musik. Pemain biola haruslah menganggap bahwa biola seolah-olah menjadi satu dengan badan, biola seperti tangan yang lain, tidak terlepas walaupun tanpa dipegang. Ada sedikit rahasia dari Stern dimana ia menggunakan bantalan dari busa di bahunya agar tidak kaku dan sakit sewaktu menjepit biola diantara dagu dan bahu. Seni permainan biola dalam hal ini penggarapan bowing (gesekan) dan fingering (sistem penjarian) diperlukan oleh pemain biola sebagai cara untuk mengekspresikan sebuah komposisi musik agar dapat diperdengarkan sesuai dengan jiwa kesenimanannya.

Dalam kaset DVD berjudul Itzhak Perlman Eugene Ormandy, sistem penjarian Perlman sering berganti posisi dengan jari yang sama di nada yang berjarak setengah seperti pada birama kedua setelah biola solo, yaitu dari nada D menuju nada Cis. Motif melodi yang sama seperti yang terjadi pada birama 4 dan 5 setelah tempo moderato assai dimainkan dengan senar yang berbeda, motif pertama Perlman menggunakan senar D lalu berpindah ke senar A di motif kedua yang dimaksudkan agar Tone Color (warna suara) lebih bervariasi. Berikut sebagian notasi dari konserto D Mayor Tschaikowsky dengan bowing dan fingering Perlman :

\section{Concerto in D Major}

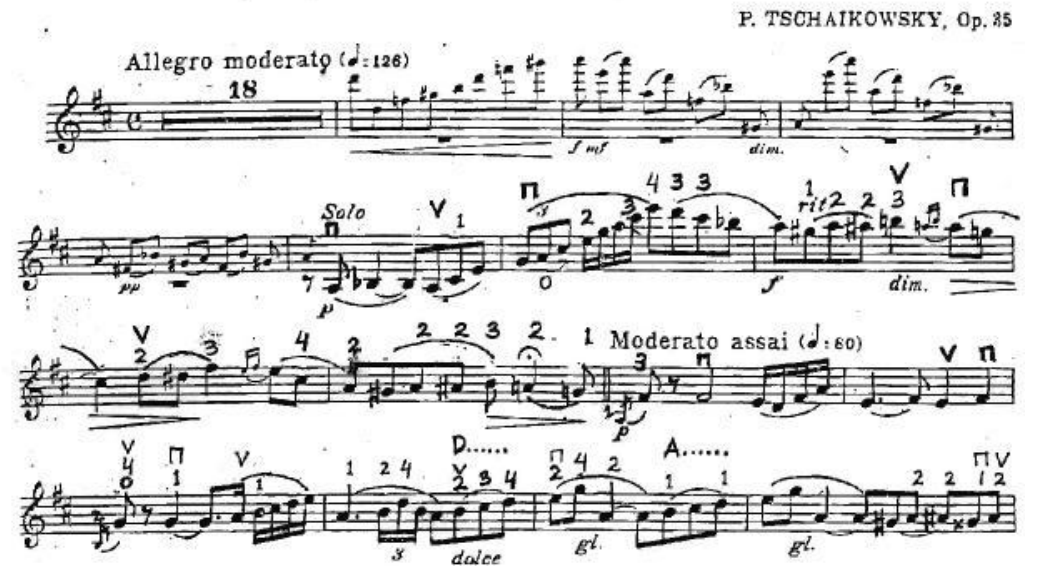

Notasi 1.

Hal yang unik dilakukan Perlman di bagian III Concerto yang sama dalam tempo Allegro vivacissimo memainkan teknik pizzicato (memetik senar) menggunakan keempat jari tangan kanan secara bergantian, yaitu jari 1-2-3 dan pada motif pengulangan yang sama menggunakan jari 2-1-4, berbeda dengan permainan Michel Rabin dan Ruggiero Ricci dalam DVD The Great Violinist yang hanya menggunakan jari 1. Perlman berusaha berkomunikasi dengan pemain orkestra lewat gerakan tubuhnya terutama dalam kalimat musik yang bergantian antara solis dan orkestra. 


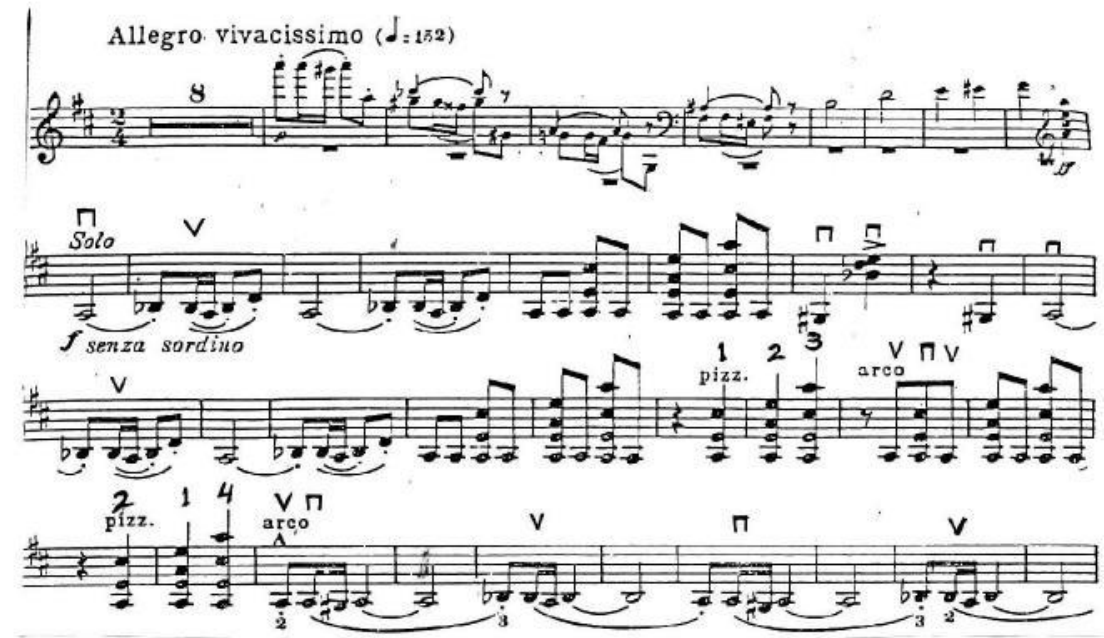

Notasi 2.

Concerto in E minor karya Mendelssohn dimainkan dengan sangat ekspresif oleh Arthur Grumiaux dalam kaset Arthur Grumiaux plays Beethoven Mendelssohn, Paganini. Penggunaan teknik stretching (perentangan jari) yaitu jari tengah dan kelingking memungkinkan Arthur untuk mencapai nada-nada tinggi di awal konserto. Whole Bow (menggesek dengan seluruh bow) ia pergunakan untuk memaksimalkan produksi suara di senar E yang merupakan senar terkecil di biola. Arthur sering menggunakan bow didekat bridge (jembatan penghubung senar dan badan biola) untuk memperoleh suara yang maksimal. Berikut contoh bowing dan fingering dari Arthur Grumiaux :

Concerto in E Minor

F. Mendelssohn

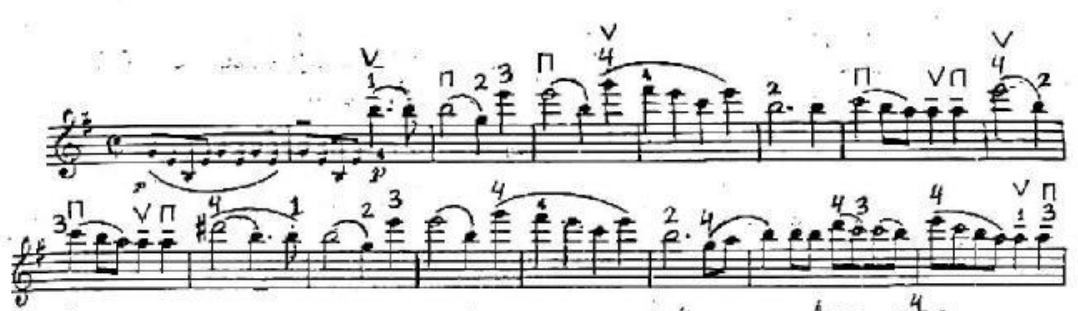

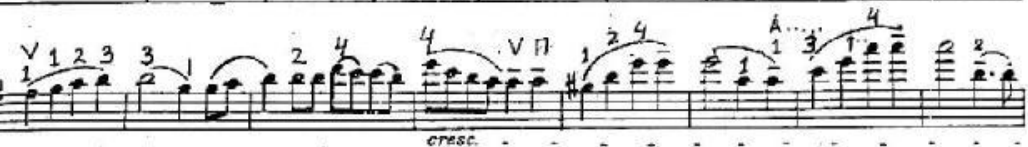

Notasi 3.
Sebagai perbandingan akan dipilih dua solis biola yaitu Henryk Szeryng dan Zino Francescatti yang memainkan konserto yang sama karya Beethoven. Szeryng menggunakan perpindahan posisi dengan penjarian 1-3-1-3 di birama 101. Permainan bowing dengan legato (nada bersambung) yang panjang dengan pengaturan bow (penggesek) yang tepat.

Zino dalam frase yang sama menggunakan perpindahan posisi dengan penjarian 1-1-3-4, jari 1 berpindah secara halus tanpa menimbulkan efek glissando (nada yang menyeret) di birama 101. Menyadari sedang diiringi dengan orkestra lengkap yang terdiri dari berbagai macam alat musik, Zino melakukan permainan bowing yang berbeda dengan Szeryng dimana lebih banyak mengganti arah gesekan (penggunaan legato yang lebih pendek) sehingga produksi suara yang dihasilkan lebih sonor (nyaring) dan solis biola tidak tertutup suaranya oleh iringan orkestra. Perbandingan bowing dan fingering antara Szeryng dan Zino :

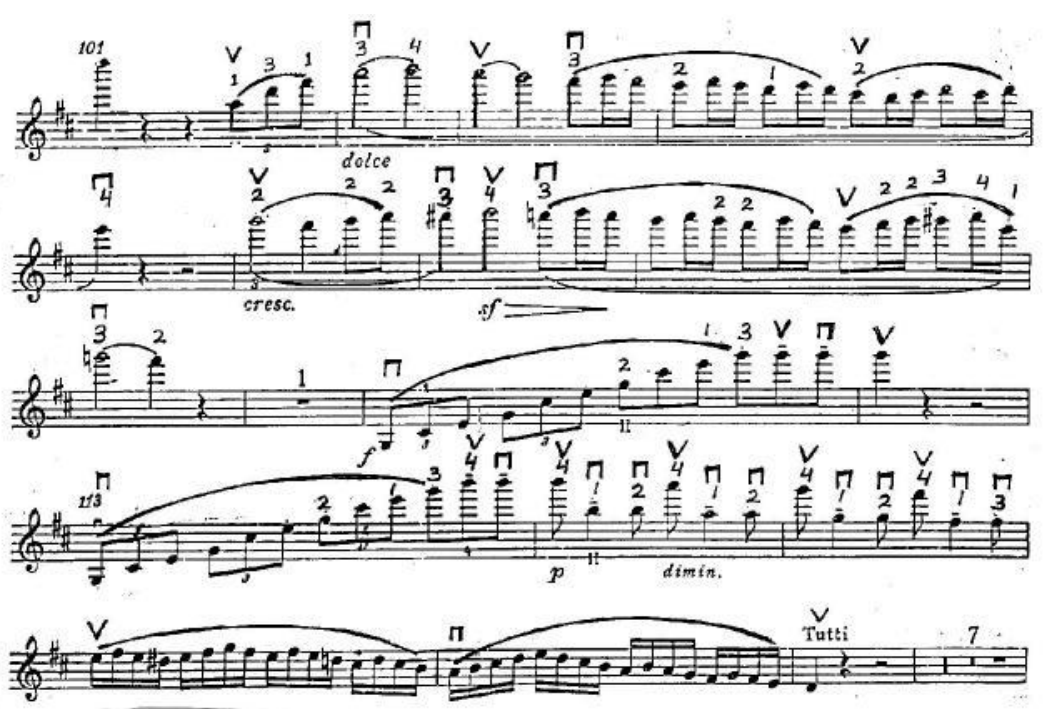

Notasi 4. versi Szeryng 

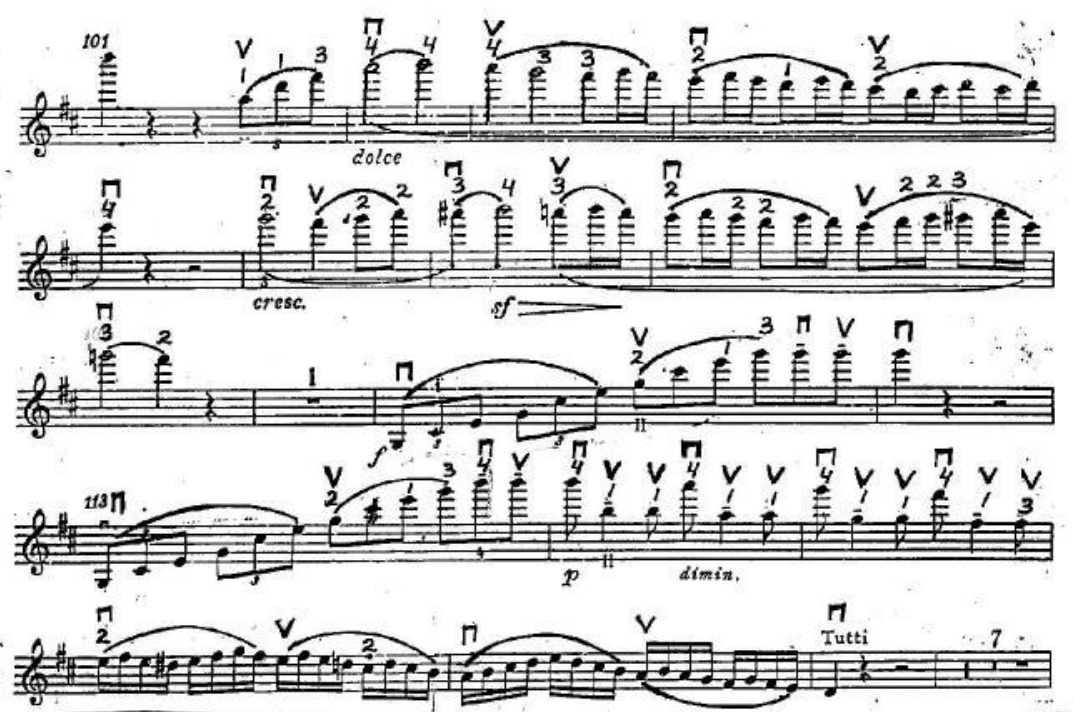

Notası J. versı Zıno

Pemain biola terkadang menghindari penggunaan jari kelingking untuk memainkan vibrato (gelombang getaran atas sebuah nada tertentu), karena kelingking merupakan jari yang terkecil sehingga kurang maksimal untuk memainkan teknik vibrato. Namun menjadi sesuatu hal yang lain dengan pemain biola Amerika dalam kaset Gil Shaham with Israel Philharmonic Orchestra, dengan jari kelingking yang kuat Gil Shaham dapat memainkan bagian awal dari tema Concerto in $\mathrm{G}$ minor karya Max Bruch dengan vibrasi yang ekspresif. Pada akhir frase ia menggunakan dua arah gesekan untuk mencapai produksi suara yang optimal. Didukung dengan konduktor yang sangat ekspresif dalam menerjemahkan kalimat musik, aba-aba yang begitu jelas terlihat memudahkan pemain orkestra dalam mengekspresikan musik lewat instrumennya. Berikut adalah contoh bowing dan fingering Gil Shaham di bagian awal dari Concerto in G minor karya Max Bruch :

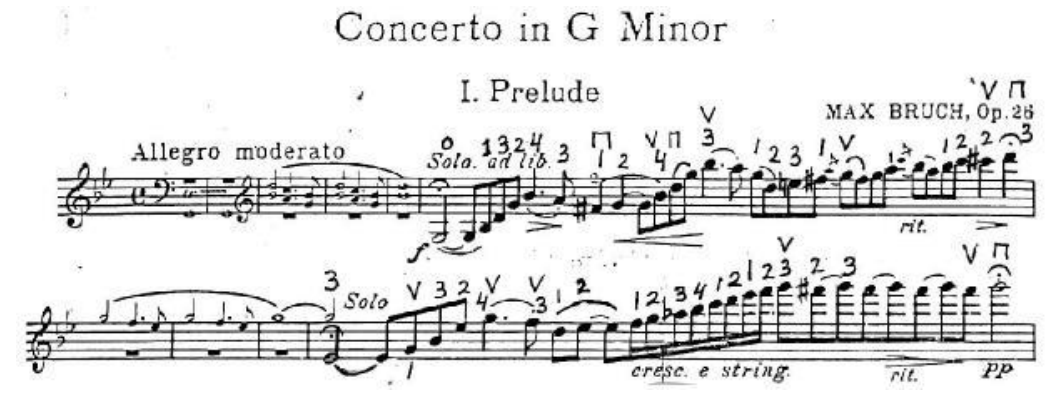

Notasi 6.

Fingering yang dipergunakan Erica Morini saat memainkan Concerto in A Mayor karya Mozart dalam kaset Netherland Radio Philharmonic sangat fleksibel. Ia berusaha mencari warna suara yang tepat dan musikal. Walaupun dengan posisi yang selalu berpindah tidak mempengaruhi intonasi dan artikulasi dalam permainannya. Permainan trill yang lembut di dua birama sebelum tempo Allegro Aperto diikuti dengan perpindahan senar yang brillian yaitu dari senar DA-E disertai penjarian yang rapi berurutan. Bowing Morini sedikit berbeda dengan bowing versi Shinichi Suzuki.

Pada bagian 2 perpindahan posisi sangat halus walaupun kadang terdengar efek glissando. Di bagian 3 tempo yang dimainkan Morini sedikit lebih lambat dari versi solis biola Gidon Kremer, teknik sostenuto sangat dominan dalam bagian 3 ini. Berikut contoh bowing dan fingering Morini di bagian awal Concerto in A Mayor karya Mozart.

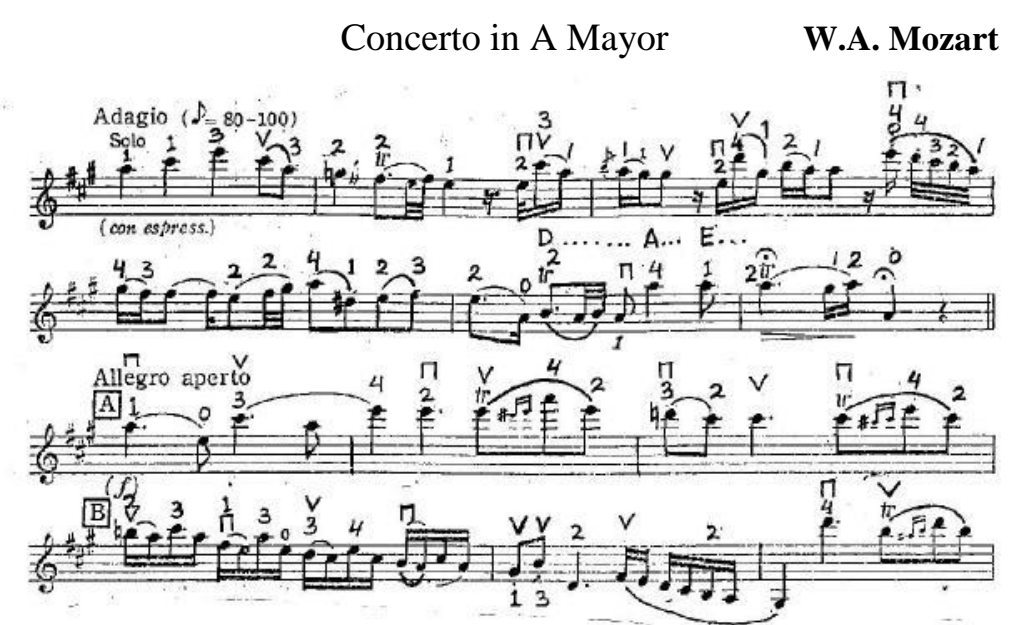

Notasi 7. 


\section{SIMPULAN}

Pertunjukan solis biola di atas dapat menjadi alternatif guna mengembangkan wawasan khususnya ketrampilan bermain biola. Masih banyak solis biola kelas dunia yang lain seperti Yehudi Menuhin, David Oistrakh, Leonid Kogan, Ruggiero Ricci, Nathan Milstein, Gidon Kremer yang bisa dicontoh dalam segi teknik permainan maupun interpretasi terhadap lagu-lagu yang dimainkannya. Minimnya instruktur musik dari luar negeri untuk memberikan workshop maupun konser musik klasik di Tanah Air bisa sedikit terobati dengan adanya kaset DVD solis biola tersebut. Pelajar dan mahasiswa jurusan musik yang telah melihat kaset tersebut diharapkan dapat lebih termotivasi untuk berlatih biola.

Seyogyanya dengan semakin banyaknya peminat di jalur musik, perlu disediakan tempat dan kegiatan sebagai ajang berekspresi untuk menyalurkan bakat kesenimanannya. Sebagai contoh, di Jurusan Musik FBS UNY telah dirintis program konser musik berkala melalui Kinarya Chamber Music dan program pentas kelas. Hal itu dirasakan bermanfaat dan patut untuk terus dikembangkan.

\section{DAFTAR PUSTAKA}

Apel, Willy. 1982. Harvard Dictionary of Music, Cambridge, Massachusett :The Belknap Press of Harvard Dictionary Press.

Banoe, Pono. 1984. Pengantar Pengetahuan Alat Musik, Jakarta : CV

Baru. Banoe, Pono. 1984. Kamus Istilah Musik, Jakarta: CV. Baru.

Kennedy, Michael. 1994. The Oxford Dictionary of Music, New York: Oxford University Press.

Midgley, Ruth (Ed.). 1976. Musical Instruments of The World. New York: Fact on File Inc.

Miller, Hugh. M. Introduction to Music, a Guide to Good Listening (Pengantar Apresiasi Musik), terj. Drs. T. Bramantyo, PS, M. Ed, P.hD.

Randel, Don Michae. 1986. The New Harvard Dictionary of Music, London, England: The Belknap Press of University Press.

Roth, Henry. 1997. Violin Virtuosos, From Paganini to the 21 Century, U.S.A : Paperback Edition.

Suzuki, Shinichi. 1974. Suzuki Violin School Volume 9. Zen-On Music Publishers Co. Ltd. 